ZałącZnIil

\title{
ZARZAৃDZANIE STRATEGICZNE MUZEUM MARTYROLOGICZNYM I MIEJSCEM PAMIĘCI NA PRZYKŁADZIE PAŃSTWOWEGO MUZEUM AUSCHWITZ-BIRKENAU W OŚWIĘCIMIU
}

AgNIESZKA PRAGA

Instytut Nauk Historycznych UKSW

Institute of Historical Sciences UKSW

praga.agnieszka@gmail.com

„Zarządzanie miejscami pamięci” jest terminem młodym, który nie we wszystkich kręgach akademickich spotyka się z pozytywnym przyjęciem. Wątpliwości związane z zasadnością używania określenia „zarządzanie pamięcią i miejscami pamięci” mogą wynikać ze skojarzeń z zarządzaniem traumą, co z oczywistych względów jest nie do przyjęcia. W dyskursie nad miejscami pamięci ${ }^{1}$, w szczególności powstałymi na terenie byłych obozów koncentracyjnych, podkreśla się przede wszystkim ich ponadczasowe znaczenie - będąc symbolem Zagłady, stanowią one jednocześnie ostrzeżenie przed kolejnymi aktami ludobójstwa, nasilającym się ekstremizmem, obojętnością na tragedię krajów ogarniętych wojną. Zagadnienia miejsc pamięci są w głównej mierze podejmowane z punktu widzenia ich znaczenia edukacyjnego - tak zwanej pedagogiki miejsc pamięci. Nie należy jednak zapominać, że miejsce pamięci, stanowiące nieodłączny element kształtowania tożsamości zbiorowej, osadzone jest przecież w realnej przestrzeni i nierzadko związane z konkretnymi pozostałościami materialnymi. Alicja Kędziora z Instytutu Kultury Uniwersytetu Jagiellońskiego podkreśla, że zarządzanie pamięcią sprowadza się do zarządzania miejscami pamięci; nie tylko niematerialnym dziedzictwem kulturowym, ale również jego materialnym wymiarem ulokowanym w określonej „kulturowej przestrzeni

1 Pojęcie „miejsca pamięci” (lieux de mémoire) wprowadził w 1984 roku francuski historyk Pierre Nora. Używali go również m.in. Hagen Schulze, Etienne Francis, Jan i Alaida Assmannowie czy Andrzej Szpociński. 
umuzealnionej” spełniającej funkcję pamiętania o przeszłości: „Miejsca pamięci nie istnieją w próżni, [ale] w określonych warunkach społeczno -ekonomicznych współtworzą przestrzeń kulturową i tylko jako takie mogą zostać w pełni odebrane i zrozumiane"2. Dlatego też tak istotne jest rozpatrywanie miejsc pamięci również pod kątem zarządzania nimi w ten sposób, by nałożone nań funkcje mogły zostać w pełni zrealizowane. Zarządzanie miejscami pamięci związane jest z zarządzaniem muzeami czy instytucjami kultury w ogóle. Ze względu na specyfikę miejsc pamięci po byłych obozach koncentracyjnych i zagłady administrowanie nimi rozszerzone jest dodatkowo na działania utrwalające wymiar autentyzmu przestrzeni poobozowych. Jak pisze A. Kędziora: „Epoka rozliczeń z przeszłością spowodowała eskalację znaczeń omawianego terminu ["miejsce pamięci“ - przyp. A.P.], a jego niezwykła kariera każe się zastanowić nad korzyściami płynącymi z użycia go także w dyscyplinie tak młodej, jaką jest zarządzanie kulturą"3. Andrzej Szpociński stawia tezę, że źródłem tak dużego powodzenia terminu „miejsca pamięci” jest uwrażliwienie kultury naszych czasów, również w jej historycznym aspekcie, na wymiar przestrzenno-wizualny ${ }^{4}$.

Państwowe Muzeum Auschwitz-Birkenau (PMA-B) jest szczególnym miejscem pamięci. O jego wyjątkowym charakterze świadczy między innymi wpisanie w 1979 roku terenu po byłym niemieckim obozie koncentracyjnym i zagłady na Listę Światowego Dziedzictwa UNESCO. Z tego miejsca pamięci płynie przesłanie dzięki autentyzmowi, zachowaniu pozostałości po byłym obozie - dzięki temu ludzkość może skonfrontować się ze swą własną historią, tożsamością i teraźniejszością. W sprawozdaniu PMA-B za rok 2016 znajdujemy informację o kolejnej rekordowej liczbie odwiedzających Miejsce Pamięci i Muzeum Auschwitz-Birkenau: 2053000 osób 5 .

2 Zob. A. Kędziora, Miejsca pamięci w zarządzaniu pamięcia o artyście, „Zarządzanie w Kulturze” 2012, nr 13, z. 2, s. 106-108.

3 Ibidem, s. 110.

4 Zob. A. Szpociński, Miejsca pamięci (lieux de mémoire), „Teksty Drugie” 2008, nr 4, s. 11.

5 P. Sawicki, Ponad 2 miliony odwiedzających Miejsce Pamięci Auschwitz-Birkenau w 2016 r., „Oś - Oświęcim - Ludzie - Historia - Kultura” 2017, nr 105 (styczeń), s. 2. 
Wyk. 1. Frekwencja w latach 2001-2016

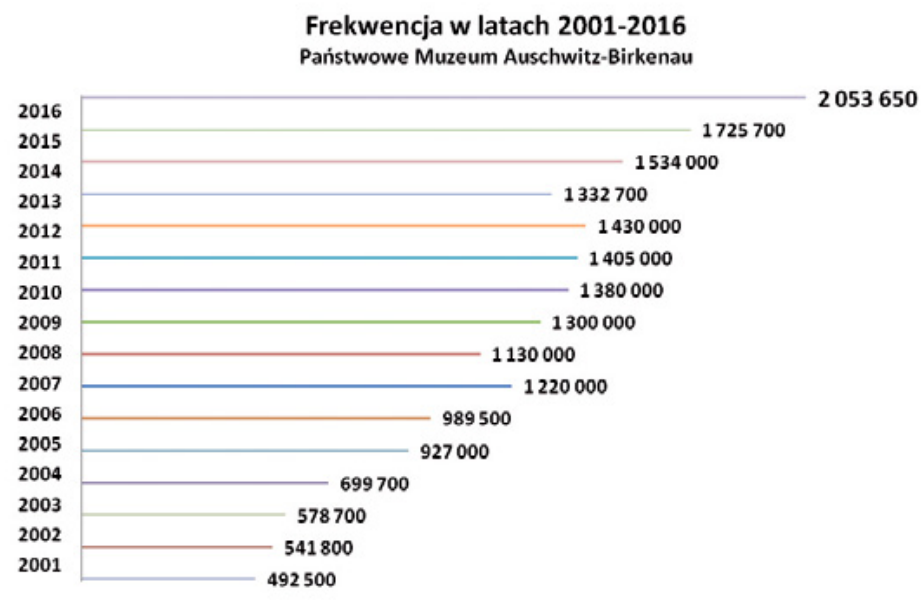

Źródło: Sprawozdanie Państwowego Muzeum Auschwitz-Birkenau w Oświęcimiu za rok 2016

W związku z dużą frekwencją Muzeum wprowadziło obowiązkową rezerwację internetową dla grup zorganizowanych oraz osób indywidualnych ${ }^{6}$. Tego typu system nie pozwala biurom turystycznym na organizowanie wejść na teren Muzeum w najbardziej obleganych godzinach. Wizyty rozłożone są na wszystkie dostępne godziny, również popołudniowe. System rezerwacji jest na bieżąco analizowany i ulepszany. Obecnie terminy wizyt można rezerwować nawet z rocznym wyprzedzeniem. Od marca 2017 roku teren byłego obozu będzie udostępniony zwiedzającym już od godziny 7.307. Ponadto odwiedzający mogą liczyć na 286 edukatorów-przewodników, władających łącznie dziewiętnastoma językami. Warto podkreślić, że żadne muzeum na świecie nie zatrudnia przewodników mówiących w tak wielu językach ${ }^{8}$. W czym tkwi „sekret” PMA-B? Czy uznanie miejsca pamięci za światowy symbol Zagłady wystarczy, by odnieść sukces frekwencyjny?

${ }^{6}$ visit.auschwitz.org [dostęp: 28.02.17].

7 P. Sawicki, op. cit., s. 3.

$8 \mathrm{http}$ //auschwitz.org/muzeum/aktualnosci/nowy-system-rezerwacji-online -w-muzeum-auschwitz,1673.html [dostęp: 28.02.17]. 
W jaki sposób udało się logistycznie zapanować nad jednym z największych na świecie obiektów chronionych Konwencją UNESCO?

Zgodnie z wywodzącą się z ekonomii koncepcją zasobów i kompetencji (wprowadzoną do literatury przez Edith Penrose ${ }^{9}$ ) wszelkie strategie budowane przez organizacje i instytucje powinny opierać się na wewnętrznych atutach tychże instytucji. Według tej koncepcji, bazowanie na atutach charakterystycznych dla danej instytucji gwarantuje jej przetrwanie w dłuższym okresie $^{10}$. W przypadku PMA-B nie trzeba daleko szukać owego „gwaranta istnienia instytucji”. Potężnym jego atutem jest przede wszystkim autentyzm miejsca pamięci - obecność infrastruktury poobozowej. Można przewrotnie stwierdzić, że w takim układzie wszelkie miejsca pamięci mają zagwarantowaną „dobrą pozycję” ze względu na swą historyczną lokalizację. Faktem jest, że ze wszystkich miejsc pamięci po byłych obozach koncentracyjnych i zagłady na terenie dawnego KL Auschwitz-Birkenau pozostało najwięcej obiektów z lat funkcjonowania obozu - jest to miejsce najmniej dotknięte upływem czasu i ingerencją ludzką. Inną trudnością zarządzania pamięcią związaną z infrastrukturą obozową i specyfiką miejsc pamięci będących jednocześnie cmentarzyskami - jest estetyka przestrzeni, pytanie o zasadność eksponowania treści i artefaktów przy pomocy nośników wykraczających poza granicę autentyzmu (technologie multimedialne). Międzynarodowych interesariuszy niełatwo przekonać o znaczeniu osobistej konfrontacji człowieka $\mathrm{z}$ terenem, na którym współczesność nie odcisnęła swego wpływu. Piotr M.A. Cywiński, dyrektor PMA-B, przytacza kilka przykładów:

Niektórzy widzą w Auschwitz miejsce, w którym powinny zaistnieć multimedia, interaktywność, atrakcje. Inni chcą więcej rekonstrukcji, ktoś kiedyś proponował oryginalnej wielkości lalki, np. esesmanów z psami czy też stojących na wieżyczkach i oślepiających przechodzących snopem światła. Propozycji takich jest multum. Pytaniem jest, czym jest Auschwitz dzisiaj [...]. Pamięć jest czynnikiem ponadczasowym, jednakże gdy jest przeżywana w autentycznym Miejscu. Zrozumienie i świadomość mają szansę osiągnąć [tu] niepowtarzalnie więcej niż przed ekranem telewizora lub nad

9 Zob. E. Penrose, The Theory of the Growth of the Firm, Oxford 1959.

10 Zob. M. Śliwa, Zarzadzanie strategiczne organizacja, [w:] Strategie dla kultury. Kultura dla rozwoju. Zarządzanie strategiczne instytucja kultury, red. M. Śliwa, Kraków 2011, s. 17. 
kartą książki. Autentyzm jest zatem tym, co należy chronić i ukazywać. Tę ochronę i to ukazywanie uważam za najważniejsze zadanie osób mających Auschwitz dzisiaj w swej opiece. Autentyzm jest paradygmatem Miejsca Pamięci. Każdego ${ }^{11}$.

Konkretne i konsekwentne stanowisko dyrektora Cywińskiego skłania, by zagadnienie zachowania autentyzmu miejsca pamięci włączyć w szerszy plan strategii, których elementem jest również wypracowanie tożsamości instytucji kultury:

Instytucja kultury przede wszystkim powinna mieć określoną, wypracowaną z jej interesariuszami tożsamość, tzn. wiedzieć, czego chce, w jaki sposób działa, i wokół tej tożsamości budować też sieć relacji z publicznością i lokalnym środowiskiem. [...] Idealnie byłoby, gdyby instytucja kultury dawała zarówno poczucie zakorzeniania, jak i możliwości przebudowania tożsamości tak, by korespondowała ona ze zmianami otaczającego nas świata. Stanowi to, oczywiście, ogromne wyzwanie dla instytucji kultury ${ }^{12}$.

Podsumowując, należałoby połączyć owe „poczucie zakorzenienia” właśnie z koncepcją zachowania autentyzmu miejsca pamięci, jeśli zaś chodzi o „przebudowę tożsamości” na miarę współczesności i zmian w otaczającym świecie - bez wątpienia można wskazać na koncepcję nowej wystawy głównej PMA-B ${ }^{13}$, wypracowywaną w ciągu dwóch i pół roku w sposób bardzo wnikliwy, z pomocą wielu ekspertów i z wykorzystaniem wiedzy na temat charakterystyki odwiedzających. Nowa wystawa będzie otwierana dla zwiedzających w trzech częściach w latach 2021-2025. Tak długi czas realizacji spowodowany jest wdrażaniem kolejnych punktów harmonogramu etapami, aby nie musieć ograniczać możliwości zwiedzania instytucji. Wedle przyjętych założeń, wystawa nie może mieć charakteru wyłącznie edukacyjnego

11 P.M.A. Cywiński, Epitafium... i inne spisane niepokoje, Oświęcim 2012, s. 90-97.

${ }_{12}$ M. Krajewski, Instytucje kultury a uczestnicy kultury. Nowe relacje, [w:] Strategie dla kultury..., op. cit., s. 34-35.

${ }_{13}$ Jej pierwsze ogólne założenia koncepcyjne zostały opracowane przez prof. Wacława Długoborskiego oraz starszych kustoszy Teresę Świebocką i Teresę Zbrzeską. W lipcu 2007 projekt został przyjęty przez Międzynarodową Radę Oświęcimską. 
i historycznego, dlatego powołano (co jest warte podkreślenia, ponieważ nie w każdym muzeum dostrzega się konieczność tego typu współpracy) interdyscyplinarny zespół zadaniowy Nowej Wystawy Głównej, w skład którego wchodzą m.in. edukator, historyk, dokumentalista, architekci ${ }^{14}$. Szczególnie istotna dla sprawnego zarządzania instytucją kultury jest zauważalna w Miejscu Pamięci i Muzeum Auschwitz-Birkenau umiejętność współpracy ludzi różnych specjalności przy jednym projekcie. Katarzyna Barańska, podejmując problematykę zarządzania z perspektywy humanistycznej, zwraca uwagę, że zazwyczaj zespół pracowników instytucji kultury boryka się z wewnętrznymi trudnościami: „Wymiana myśli teoretycznej oraz doświadczeń z zakresu tzw. dobrych praktyk przeważnie odbywa się "we własnym gronie« - osobno organizowane są konferencje dla konserwatorów, edukatorów czy kustoszy. Każdy boi się wyjść poza swoją specjalność lub dopuścić do niej kogoś z zewnątrz »branży«"15.

Według rekomendowanego schematu organizacyjnego placówek muzealnych:

[...] bez względu na rodzaj sprawowanego nadzoru struktura funkcjonowania współczesnego muzeum powinna być oparta na tzw. sześcianie zadań, na który składa się współpraca trzech pionów muzeum: opieki nad zbiorami (kuratoria, konserwacja, dokumentacja); realizacji programów-projektów (organizacja wystaw, projektowanie, edukacja, wydawnictwa, public relations, marketing); administracji (kadry, dział finansowy i księgowy, obsługa prawna, dział rozwoju, inwestycji i remontów, ochrona, dział obsługi zwiedzających i korzystających ze zbiorów, utrzymanie porządku). Każdy $\mathrm{z}$ trzech pionów muzeum powinien być kierowany przez specjalistę $\mathrm{w}$ danym zakresie: muzeologa, specjalistę co najmniej II stopnia; muzeologa z dodatkowym wykształceniem w zakresie edukacji, PR lub marketingu; specjalistę ds. zarządzania z wykształceniem ekonomicznym, prawnym lub technicznym ${ }^{16}$.

${ }^{14}$ Informacje uzyskane dzięki uprzejmości Alicji Białeckiej, pełnomocnika ds. Nowej Wystawy Głównej PMA-B.

${ }^{15} \mathrm{~K}$. Barańska, Muzeum w sieci znaczeń. Zarzadzanie z perspektywy nauk humanistycznych, Kraków 2013, s. 212.

16 D. Folga-Januszewska, Muzea w Polsce 1989-2008. Stan, zachodzace zmiany i kierunki rozwoju muzeów $w$ Europie oraz rekomendacje dla muzeów w Polsce, Warszawa 2008, s. 37. 
Współpraca między tymi pionami jest niezbędna, nie mogą one działać na zasadzie odrębnych jednostek. Dział administracji odpowiadający m.in. za inwestycje i remonty nie powinien funkcjonować niezależnie, ponieważ jego działania bezpośrednio dotyczą również filaru odpowiedzialnego za opiekę nad zbiorami.

Mieczysław Porębski wskazywał, że „muzeum idealne jest przede wszystkim dobrze zorganizowane". Wyjaśniał, że niezwykle istotne jest zachowanie odpowiednich proporcji $\mathrm{w}$ realizacji zadań między pracownikami merytorycznymi a administracyjnymi i technicznymi. Barańska rozwija tę myśl i dodaje, że w strategii zarządzania każdym projektem należy zwracać uwagę nie tylko na właściwe przydzielanie zadań i rozliczanie efektów pracy, ale w równej mierze trzeba budować zespół pracowniczy, który opiera się na wielu specjalnościach (merytorycznych, konserwatorskich, edukacyjnych) ${ }^{17}$. Dobrym przykładem realizacji tych postulatów są zespoły powoływane w Państwowym Muzeum Auschwitz-Birkenau m.in. przy realizacji Nowej Wystawy Głównej, jak również przy Globalnym Planie Konserwacji i Zachowania Miejsca Pamięci Auschwitz-Birkenau. Do realizacji projektu powołano trzydziestoosobowy „team”: konserwatorów zabytków, inżynierów budownictwa różnych specjalności, rzemieślników, chemików, prawników, finansistów, księgowych ${ }^{18}$. Dowodzi to dojrzałości przy planowaniu strategii realizowania kluczowych projektów w oparciu o interdyscyplinarny zespół ekspercki.

Jednym z głównych filarów planu strategicznego PMA-B jest także ochrona zbiorów i konserwacja architektonicznych pozostałości poobozowych. Wiele placówek sporządza plan strategii dotyczącej zbiorów. Plan strategiczny obejmuje tylko główne punkty, jak charakterystyka zbiorów, inwentaryzacja i dokumentacja, badania, zachowanie zbiorów i zarządzanie nimi oraz tworzenie nowych kolekcji. Uwagę kieruje się przede wszystkim w stronę takich zagadnień, jak:

- zakres zbiorów muzeum;

- trzon zbiorów;

- odpowiedź na pytanie, jaką funkcję spełniają zbiory wobec publiczności;

17 Zob. K. Barańska, op. cit., s. 167, 211-212.

18 Informacje uzyskane dzięki uprzejmości Anny Łopuskiej z Działu Konserwacji PMA-B, koordynatorki Globalnego Planu Konserwacji. 
- odpowiedź na pytanie, pod jakim względem zbiory te różnią się od kolekcji innych muzeów ${ }^{19}$.

Strategia konserwacji obiektów nieruchomych PMA-B jest tak rozbudowana, że zasługuje na odrębną analizę. Pozostając przy zagadnieniach związanych konkretnie z zarządzaniem projektami, bez wątpienia należy wspomnieć o bezprecedensowym przedsięwzięciu, jakim jest ustanowiony w 2009 roku Globalny Plan Konserwacji i Zachowania Miejsca Pamięci Auschwitz-Birkenau ${ }^{20}$ oraz Kapitał Wieczysty Fundacji Auschwitz-Birkenau, rozszerzony w kolejnych latach o osiemnaście Filarów Pamięci. Fundacja Auschwitz-Birkenau ${ }^{21}$ współpracuje $\mathrm{z}$ trzydziestoma sześcioma państwami, dwoma miastami ${ }^{22}$ oraz darczyńcami indywidualnymi. W 2016 roku działalność fundraisingową Fundacji wspomógł Ronald S. Lauder ${ }^{23}$, powołując do życia Auschwitz-Birkenau Foundation Committee. W każdym sprawozdaniu rocznym PMA-B można odnaleźć konkretne kwoty przeznaczone na wyszczególnione zadania zaplanowane na dany rok, co jest przykładem transparentności przepływu środków finansowych. Jest to pierwsza na świecie tego typu instytucja, która wypracowała tak doskonały projekt ochrony dziedzictwa, włączający również inne kraje i indywidualne osoby z całego świata. Aby zrozumieć skalę przedsięwzięcia, należy pamiętać, że obszar ochronny obejmuje około dwadzieścia hektarów byłego obozu Auschwitz I oraz 171 hektarów Birkenau. Na terenie tym znajduje się 155 budynków, 300 ruin (m.in. komór gazowych i krematoriów, relikty po barakach), sieci kanalizacji i rowy melioracyjne, drogi, trzynaście kilometrów ogrodzenia

19 Nowoczesne zarzadzanie muzeum. Wspótpraca polsko-holenderska $w$ ramach projektu MATRA 1999-2007, red. J. Czaj, B. Ziemnicka-Darnowska, P. Pawlina, Warszawa 2017, s. 39-40.

20 Jego realizację rozpoczęto w czerwcu 2012 roku.

${ }^{21}$ Fundacja Auschwitz-Birkenau powstała w 2009 roku, by zarządzać Kapitałem Wieczystym. Roczne odsetki z Funduszu wynoszą 4-5 milionów euro, co pozwala na realizację założeń konserwacyjnych.

${ }^{22}$ www.fundacja.auschwitz.org/index.php/darczyncy/panstwa [dostęp: 28.02.17].

${ }^{23}$ Ronald S. Lauder - amerykański biznesmen i filantrop, przewodniczący Światowego Kongresu Żydów i założyciel Fundacji Laudera, od 2012 roku członek Międzynarodowej Rady Oświęcimskiej. 
z ponad trzema tysiącami słupów betonowych oraz - znajdujące się na ekspozycji i w magazynach - tysiące poobozowych obiektów ruchomych i archiwalia ${ }^{24}$. Stałej konserwacji poddawana jest również zieleń niska i drzewostany, m.in. dwadzieścia hektarów lasu.

Nie trzeba przekonywać o niedofinansowaniu polskich muzeów. Szczególnie boleśnie odczuwają to muzea na terenie byłych obozów koncentracyjnych i zagłady, których obszar jest dużo bardziej rozległy niż typowych muzeów historycznych. W cytowanej już książce Nowoczesne zarządzanie muzeum Herman Aarts i Kees Plaisier przedstawiają definicję muzeum jako przedsiębiorstwa:

Muzeum to instytucja niedochodowa, ale prowadzona jak przedsiębiorstwo, które dostarcza takich produktów, jak wystawy czy projekty dla szkół. Produkty przedsiębiorstwa sprzedawane są w celu wypracowania zysku, podstawą zaś finansowania muzeum jest dotacja z budżetu państwa. Wpływy od klientów, czyli osób odwiedzających placówkę, pokrywają jedynie niewielką część kosztów eksploatacji. Państwo dotuje muzea w ramach polityki kulturalnej, ukierunkowanej na podkreślenie ich uczestnictwa w kulturze i roli w zachowaniu dziedzictwa kulturowego ${ }^{25}$.

Definicja ta nie do końca współgra z PMA-B, które będąc muzeum martyrologicznym, nie może pobierać opłat od odwiedzających za możliwość wejścia na teren poobozowy, więc nie możemy w tym wypadku mówić o typowych „wpływach od klientów”. Poniżej przedstawiona została tabela ukazująca źródła finansowania PMA-B w poszczególnych latach, począwszy od 2006 roku, kiedy po raz pierwszy Muzeum udostępniło opinii publicznej sprawozdanie ze swej działalności. W 2006 roku dotacja Ministerstwa Kultury i Dziedzictwa Narodowego (na wydatki bieżące i wydatki majątkowe) w wysokości 10,3 mln zł nieznacznie przewyższała sumę przychodów własnych Muzeum (10,2 mln zł). Co ciekawe, z upływem lat przychody własne Muzeum (59,2 \%) przewyższyły ponad dwukrotnie dotacje z MKiDN (25,6\%).

${ }^{24}$ www.fundacja.auschwitz.org/index.php/aktualnosci/32-globalny-plan-konserwacji-rozpoczety [dostęp: 28.02.17].

${ }^{25}$ Nowoczesne zarzadzanie muzeum..., op. cit., s. 16. 
Wyk. 2. Źródła finansowania Państwowego Muzeum Auschwitz-Birkenau

\begin{tabular}{|c|c|c|c|c|c|c|c|c|c|c|c|}
\hline & 2006 & 2007 & 2008 & 2009 & 2010 & 2011 & 2012 & 2013 & 2014 & 2015 & 2016 \\
\hline $\begin{array}{l}\text { Przychody wła- } \\
\text { sne Muzeum }\end{array}$ & $\begin{array}{l}10,2 \\
\mathrm{mln}\end{array}$ & $\begin{array}{l}11,5 \\
\mathrm{mln}\end{array}$ & $\begin{array}{c}13 \\
\mathrm{mln}\end{array}$ & $\begin{array}{l}16,2 \\
\mathrm{mln}\end{array}$ & $\begin{array}{l}20,2 \\
\mathrm{mln}\end{array}$ & $\begin{array}{l}22,3 \\
\mathrm{mln}\end{array}$ & $\begin{array}{l}24,8 \\
\mathrm{mln}\end{array}$ & $\begin{array}{l}26,7 \\
\mathrm{mln}\end{array}$ & $\begin{array}{l}28,6 \\
\mathrm{mln}\end{array}$ & $\begin{array}{c}33,4 \\
\mathrm{mln}\end{array}$ & $\begin{array}{l}39,5 \\
\mathrm{mln}\end{array}$ \\
\hline $\begin{array}{l}\text { Dotacja } \\
\text { Ministerstwa } \\
\text { Kultury } \\
\text { i Dziedzictwa } \\
\text { Narodowego }\end{array}$ & $\begin{array}{l}10,3 \\
\mathrm{mln}\end{array}$ & $\begin{array}{c}11 \\
\mathrm{mln}\end{array}$ & $\begin{array}{l}12,7 \\
\mathrm{mln}\end{array}$ & $\begin{array}{l}11,6 \\
\mathrm{mln}\end{array}$ & $\begin{array}{l}11,2 \\
\mathrm{mln}\end{array}$ & $\begin{array}{c}11 \\
\mathrm{mln}\end{array}$ & $\begin{array}{l}15,7 \\
\mathrm{mln}\end{array}$ & $\begin{array}{l}15,3 \\
\mathrm{mln}\end{array}$ & $\begin{array}{l}14,7 \\
\text { mln }\end{array}$ & $\begin{array}{l}16,7 \\
\mathrm{mln}\end{array}$ & $\begin{array}{l}17,1 \\
\mathrm{mln}\end{array}$ \\
\hline $\begin{array}{l}\text { Środki celowe } \\
\text { Ministra } \\
\text { Kultury } \\
\text { i Dziedzictwa } \\
\text { Narodowego }\end{array}$ & - & - & - & - & $\begin{array}{l}9,6 \\
\text { mln }\end{array}$ & $\begin{array}{c}4,2 \\
\mathrm{mln}\end{array}$ & $\begin{array}{l}0,7 \\
\mathrm{mln}\end{array}$ & $3 \mathrm{mln}$ & $\begin{array}{c}4,1 \\
\text { mln }\end{array}$ & $\begin{array}{c}3,9 \\
\mathrm{mln}\end{array}$ & $\begin{array}{c}2,5 \\
\mathrm{mln}\end{array}$ \\
\hline $\begin{array}{l}\text { Fundusze } \\
\text { pozyskane } \\
\text { z zagranicy }\end{array}$ & $\begin{array}{l}266 \\
\text { tys. }\end{array}$ & $\begin{array}{l}754 \\
\text { tys. }\end{array}$ & $\begin{array}{c}1,5 \\
\mathrm{mln}\end{array}$ & $\begin{array}{l}600 \\
\text { tys. }\end{array}$ & $\begin{array}{l}400 \\
\text { tys. }\end{array}$ & - & - & - & -1 & $\begin{array}{c}2,4 \\
\mathrm{mln}\end{array}$ & - \\
\hline $\begin{array}{l}\text { Dotacja } \\
\text { w ramach } \\
\text { Europejskiego } \\
\text { Programu } \\
\text { Operacyjnego } \\
\text { Infrastruktura } \\
\text { i Środowisko } \\
\end{array}$ & - & - & - & $\begin{array}{l}2,5 \\
\mathrm{mln}\end{array}$ & $\begin{array}{c}3,1 \\
\operatorname{mln}\end{array}$ & $\begin{array}{c}1,2 \\
\mathrm{mln}\end{array}$ & $\begin{array}{c}6,5 \\
\mathrm{mln}\end{array}$ & $\begin{array}{l}1,9 \\
\text { mln }\end{array}$ & $\begin{array}{c}2,2 \\
\text { mln }\end{array}$ & - & - \\
\hline $\begin{array}{l}\text { Programy } \\
\text { unijne }\end{array}$ & - & - & - & - & - & $\begin{array}{c}6,9 \\
\mathrm{mln}\end{array}$ & $\begin{array}{c}4,1 \\
\mathrm{mln}\end{array}$ & $\begin{array}{c}4,2 \\
\mathrm{mln}\end{array}$ & - & - & $\begin{array}{l}1,3 \\
\mathrm{mln}\end{array}$ \\
\hline $\begin{array}{l}\text { Fundacja } \\
\text { Pamięci Ofiar } \\
\text { Obozu Zagłady } \\
\text { Auschwitz- } \\
\text {-Birkenau } \\
\text { w Oświęcimiu }\end{array}$ & - & - & - & $\begin{array}{l}100 \\
\text { tys. }\end{array}$ & $\begin{array}{l}600 \\
\text { tys. }\end{array}$ & $\begin{array}{l}300 \\
\text { tys. }\end{array}$ & $\begin{array}{c}1,8 \\
\mathrm{mln}\end{array}$ & $\begin{array}{c}2,1 \\
\mathrm{mln}\end{array}$ & $\begin{array}{c}2,2 \\
\mathrm{mln}\end{array}$ & $\begin{array}{l}79 \\
\text { tys. }\end{array}$ & $\begin{array}{c}32 \\
\text { tys. }\end{array}$ \\
\hline $\begin{array}{l}\text { Volkswagen } \\
\text { / Między- } \\
\text { narodowy } \\
\text { Komitet } \\
\text { Oświęcimski }\end{array}$ & - & - & - & - & - & - & - & - & $\begin{array}{c}1,2 \\
\operatorname{mln}\end{array}$ & $\begin{array}{c}0,3 \\
\mathrm{mln}\end{array}$ & - \\
\hline $\begin{array}{l}\text { Fundacja } \\
\text { Auschwitz- } \\
\text { Birkenau } \\
\end{array}$ & - & - & - & - & - & - & - & - & - & $\begin{array}{c}5,2 \\
\mathrm{mln}\end{array}$ & $\begin{array}{l}5,9 \\
\text { mln }\end{array}$ \\
\hline NIMOZ & - & 1- & - & - & - & - & - & I & - & $\begin{array}{c}15 \\
\text { tys. }\end{array}$ & - \\
\hline
\end{tabular}

Źródło: Opracowanie własne na podstawie danych statystycznych dostępnych $w$ corocznym sprawozdaniu PMA-B (okres 2006-2016) 
Istotnym elementem strategii zarządzania są również partnerstwa strategiczne, umiejętna współpraca i utrzymywanie kontaktu z instytucjami międzynarodowymi, krajowymi i lokalnymi czy administracją publiczną (szeroki zakres współpracy ukazuje powyższa tabela źródeł finansowania). PMA-B w ciągu wieloletniej działalności w sposób znaczący rozbudowało ten typ kanału komunikacyjnego, wymiany doświadczeń i wsparcia międzyorganizacyjnego. Na szczególną uwagę zasługuje m.in. Międzynarodowa Rada Oświęcimska przy Premierze RP (MRO), powołana w 1990 roku decyzją Ministra Kultury i Sztuki. MRO stanowi międzynarodowy organ opiniodawczo-doradczy składający się z wielu ekspertów i autorytetów; jest doskonałą przestrzenią dla wymiany myśli, doświadczeń i propozycji. Podczas posiedzeń MRO nigdy nie zabrakło miejsca dla przedstawicieli pozostałych miejsc pamięci - m.in. Płaszowa, Sobiboru, Majdanka, Treblinki czy Stutthofu. Poza MRO przy Muzeum funkcjonuje również Rada Muzeum, Rada Fundacji Auschwitz-Birkenau oraz Rada Międzynarodowego Centrum Edukacji o Auschwitz i Holocauście. W moim odczuciu, sukces PMA-B polega m.in. właśnie na budowaniu trwałych i owocnych relacji z instytucjami, autorytetami i ekspertami, dzięki czemu siła przekazu jest jeszcze mocniejsza, a zasięg oddziaływania na świecie wciąż się poszerza. Jest to również dowód na skuteczność strategii zarządzania opartej na współdziałaniu w zespole.

Budowanie skutecznej komunikacji zewnętrznej w instytucjach kultury jest możliwe dzięki stosowaniu następujących zasad:

- prostoty przekazu;

- konkretności (fakty, wydarzenia, które odwiedzający mogą bezpośrednio odnieść do własnego życia);

- wiarygodności;

- emocjonalności (nostalgia, wspomnienia, utożsamienie);

- opowieści ${ }^{26}$.

Dokumentem łączącym wszystkie te punkty jest wspomniane już wcześniej roczne sprawozdanie, prezentujące najważniejsze wydarzenia, plany, badania, bieżące zadania czy statystykę odwiedzających począwszy od 2006 roku. Sprawozdanie wzbogacone zostało przejrzystymi raportami

26 R. Stocki, Dialog strategiczny w instytucji kultury. Przykład: Wawel i przewodnicy, [w:] Strategie dla kultury..., s. 170-172. 
dotyczącymi finansowania Muzeum oraz działalności Fundacji Auschwitz-Birkenau. Jest ono również ukłonem w stronę pracowników Muzeum podkreśla ich pracę na rzecz ochrony dziedzictwa: „Ten raport to opowieść o ludziach, którzy wybrali swoją własną odpowiedź na te pytania. Oddali swój czas, swoje siły, emocje i nadzieje, aby odpowiedzialnie zająć się na co dzień tym przerażającym Miejscem Prawdy"27.

Katarzyna Barańska w pracy Muzeum w sieci znaczeń. Zarządzanie zperspektywy nauk humanistycznych zauważa, że w minionych latach wiele muzeów decydowało się umieścić na stronach internetowych swoich placówek strategię działania czy misję. Niestety, specjalistyczny charakter tych informacji oraz specyficzny język powodują, że odbiorca nie uzyskuje interesujących wiadomości odnoszących się do aktywności danej placówki ${ }^{28}$. Natomiast pojawienie się sprawozdania PMA-B spotkało się z wielkim zainteresowaniem w Polsce i na świecie. W związku z tym Muzeum w każdym wydaniu postanowiło zaprezentować tak zwane międzynarodowe głosy poparcia, świadczące o potrzebie istnienia dokumentu dostępnego dla wszystkich i jednocześnie utwierdzającego przedstawicieli i pracowników Muzeum w przekonaniu, że wraz z kierunkiem, w jakim podążają, mają wokół siebie coraz więcej międzynarodowego wsparcia. „Jestem przekonany, że informowanie w takiej formie także społeczeństw poza granicami Polski o działalności instytucji muzealnej przyczyni się do umocnienia pamięci o tragedii i ofiarach II wojny światowej w skali międzynarodowej"29 - stwierdził Tomas Bertelman, ambasador Szwecji. W podobnym tonie wypowiedział się Pascala Couchepin, ówczesny prezydent Konfederacji Szwajcarskiej: „Zauważyłem z satysfakcją stabilny wzrost liczby odwiedzających, jak również rozwój projektów edukacyjnych i postęp badań naukowych. Poza tym fakt, że przygotowują Państwo w tej chwili nową wystawę główną, pokazuje, że Muzeum jest ciągle przygotowane na podejmowanie nowych wyzwań" ${ }^{\prime 30}$.

27 Sprawozdania Państwowego Muzeum Auschwitz-Birkenau w Oświęcimiu za rok 2014, s. 4.

${ }_{28}$ K. Barańska, op. cit., s. 209.

${ }_{29}$ Sprawozdanie Państwowego Muzeum Auschwitz-Birkenau w Oświęcimiu za rok 2007, s. 5 .

30 Sprawozdanie Państwowego Muzeum Auschwitz-Birkenau w Oświęcimiu za rok 2008, s. 7. 
Jaki był pierwotny cel cyklicznego wydawania raportu? Dyrektor Muzeum, Piotr M.A. Cywiński, w sprawozdaniu za rok 2006 napisał:

Pierwszy raz w historii instytucji opiekującej się jednym z najważniejszych miejsc na ziemi przedstawiam Wam, w tej formie, roczny raport $\mathrm{z}$ naszej działalności. Głównymi naszymi zadaniami są oczywiście ochrona i konserwacja reliktów poobozowych, prowadzenie badań naukowych, rozwój programów edukacyjnych. Potrzeby są olbrzymie. Wydarzenia na świecie pokazują, jak w sumie niewiele nasza cywilizacja nauczyła się ze swej przeszłości. Dlatego chciałbym przedstawić Wam ludzi, którzy tworzą to Muzeum: konserwatorów, historyków, edukatorów, specjalistów w dziedzinie muzeologii. Od ich zaangażowania, fachowości i oddania zależeć będzie obraz tego Miejsca w najbliższej przyszłości ${ }^{31}$.

Kolejnym znaczącym elementem strategii zarządzania muzeum, który warto poruszyć, odnosząc się do przykładu Miejsca Pamięci i Muzeum Auschwitz-Birkenau, jest budowanie relacji ze zwiedzającym, czy szerzej - z publicznością:

[Dla MPA-B kluczowe jest - przyp. A.P.] budowanie porozumienia między wszystkimi osobami, które mają wpływ na funkcjonowanie muzeum, czyli nie tylko zwiedzającymi, ale i instytucjami wokół, które mogą [nas] wspierać. $\mathrm{W}$ planie strategicznym należy podać, na jakie grupy publiczności muzeum zamierza ukierunkować swoją działalność, w jaki sposób chce to osiągnąć, jakie planuje z myślą o nich zajęcia i wydarzenia. W przypadku większych muzeów w planie strategicznym powinien znaleźć się osobny plan dotyczący komunikacji z odbiorcami oferty muzealnej. W planie strategicznym należy określić, jakie dodatkowe działania mogą posłużyć pozyskaniu większej i bardziej zróżnicowanej publiczności, jakie zajęcia i wydarzenia skłonią ludzi do odwiedzenia muzeum i jak praca na rzecz pozyskania zwiedzających wpisuje się w misję muzeum ${ }^{32}$.

Przykładem tego typu działań jest m.in. włączenie historii KL Auschwitz-Birkenau pod postacią dwóch wirtualnych wystaw w projekt „Google

${ }^{31}$ Sprawozdanie Państwowego Muzeum Auschwitz-Birkenau w Oświęcimiu za rok 2006, s. 4.

${ }^{32}$ Ibidem, s. 44. 
Cultural Institute" (od października 2012 roku). W ramach platformy współpracuje ze sobą siedemnaście instytucji z całego świata, które podjęły się zadania przedstawienia historii XX wieku przy pomocy zdigitalizowanych materiałów archiwalnych. Umożliwia to również bardziej rzetelne przygotowywanie przez uczniów i nauczycieli prezentacji na szkolne zajęcia. Dodatkowym kanałem komunikacji stały się w ostatnich latach fora społecznościowe. Według sprawozdania rocznego za roku 2014, facebookowa strona www.facebook.com/auschwitzmemorial jako pierwszy na świecie serwis o tym profilu przekroczyła liczbę stu tysięcy subskrybentów. W 2016 roku liczba ta wzrosła do dwustu trzydziestu tysięcy. Strona przygotowana w kilkunastu językach dociera do odbiorców na całym świecie. Ponad trzydzieści tysięcy osób obserwuje muzealne konto na Twitterze, a na Instagramie liczba obserwujących sięga dwudziestu dwóch tysięcy. W 2016 roku na stronie www.auschwitz.org odnotowanych zostało ponad czterdzieści trzy miliony odsłon ${ }^{33}$. Nie sposób przy tej okazji nie wspomnieć o platformie e-learningowej skierowanej do osób, które nie są w stanie osobiście pojawić się w Miejscu Pamięci lub po prostu pragną w domowym zaciszu pogłębić wiedzę na temat historii obozu.

Poruszając kwestię relacji ze społeczeństwem i potencjalnym odbiorcą oferty muzealnej, należy wspomnieć o tak zwanych interesariuszach (stakeholders). Pod pojęciem tym mogą kryć się również instytucje, na które Muzeum ma wpływ i które oddziałują zwrotnie na Muzeum. Innymi słowy, istnieje między nimi ścisła relacja (jak na przykład w przypadku stałych partnerstw i współpracy międzyorganizacyjnej). Można wyróżnić cztery kategorie interesariuszy:

- środowisko społeczne, organy administracji publicznej oraz instytucje, $\mathrm{z}$ którymi muzeum utrzymuje kontakty w najszerszym tego słowa znaczeniu ${ }^{34}$;

33 P. Sawicki, op. cit., s. 3.

34 Jako przykład można podać przywoływane już: Międzynarodową Radę Oświęcimską, Centrum Dialogu i Modlitwy, Międzynarodowy Dom Spotkań Młodzieży w Oświęcimiu, Międzynarodowe Centrum Edukacji o Auschwitz i Holocauście, Instytut Pamięci Yad Vashem, Muzeum i Miejsce Pamięci w Terezinie, Centrum Rady Europy, Uniwersytet Jagielloński, Uniwersytet Pedagogiczny w Krakowie i wiele innych. 
- publiczność, składająca się z przedstawicieli grup docelowych, jak i z osób zwiedzających muzeum indywidualnie, uczniów oraz pracowników innych instytucji;

- sponsorzy - instytucje oraz osoby prywatne udzielające wsparcia materialnego (Kapitał Wieczysty, 18 Filarów Pamięci i inni darczyńcy);

- pracownicy muzeum (istnienie muzeum leży w ich interesie, oni także są niezbędni do prawidłowego funkcjonowania placówki) ${ }^{35}$.

Analiza rodzajów interesariuszy może posłużyć do ukazania pozycji, jaką muzeum zajmuje na rynku, oraz poziomu realizacji wzajemnych oczekiwań w relacji muzeum - odbiorca. Tego typu badania wciąż nie są jednak powszechnym elementem w zarządzaniu dziedzictwem i polskimi instytucjami kulturalnymi. Tylko nieliczne muzea mogą np. wskazać poziom rocznej frekwencji w swojej siedzibie:

Obecnie w Polsce uczestnictwo w kulturze nie jest, a powinno być, ważną kategorią. Problemem większości instytucji kultury jest przede wszystkim to, że mają bardzo małą wiedzę na temat tego, kto jest ich klientem i kto korzysta $z$ ich usług. [...] Po pierwsze, w Polsce nieliczne instytucje gromadzą jakiekolwiek badania. Na palcach jednej ręki można wyliczyć te, które z własnej woli tego rodzaju analizy wykonują. [...] Nie ma jakiejkolwiek pogłębionej charakterystyki publiczności, informacji na temat jej potrzeb, oczekiwań, tego, jak ocenia ona działania instytucji $[\ldots]^{36}$.

PMA-B co roku wykonuje szczegółowe badania statystyczne dotyczące odwiedzających - w sprawozdaniu rocznym znajdują się zestawienia osób zwiedzających z wyszczególnieniem kategorii wiekowej czy kraju pochodzenia. Wykorzystanie wiedzy dotyczącej grup docelowych przekłada się m.in. na zmianę sposobu oprowadzania po terenie byłego obozu (od 2012 roku) czy koncepcję zupełnie nowej wystawy głównej, dostosowanej do współczesnego odbiorcy. PMA-B w praktyce wykorzystało również wiedzę na temat odwiedzających np. poprzez udostępnienie wszystkim bezpłatnego autobusu kursującego między Auschwitz I a Birkenau, ustalenie wspomnianego wcześniej nowego regulaminu rezerwacji terminów wizyty oraz wydanie publikacji umożliwiającej przygotowanie do wizyty w miejscu

35 Nowoczesne zarzadzanie muzeum..., op. cit., s. 30-31.

${ }^{36}$ M. Krajewski, op. cit., s. 27. 
pamięci i kierującej uwagę nauczycieli oraz edukatorów na fakt, jak bardzo potrzebna jest rozmowa podsumowująca i porządkująca silne doświadczenia emocjonalne po zakończeniu wizyty w Muzeum ${ }^{37}$.

W 2016 roku Międzynarodowe Centrum Edukacji o Auschwitz i Holocauście po raz pierwszy zrealizowało angielskojęzyczne seminarium Historia - Pamięć - Odpowiedzialność dla grupy zawodowej dziennikarzy. Związane jest to nie tylko $\mathrm{z}$ odpowiedzią na zapotrzebowanie społeczne upowszechniania wiedzy o Zagładzie, ale także $\mathrm{z}$ istotnym elementem zarządzania miejscem pamięci, jakim jest zapobieganie i przeciwdziałanie manipulacji, instrumentalizacji i innym trudnościom związanym ze współpracą $z$ mediami. We wspomnianym seminarium wzięli udział dziennikarze z Australii, Francji, Izraela, Niemiec, Stanów Zjednoczonych, Szwecji i Wielkiej Brytanii. Uczestnikami byli m.in. korespondenci największych światowych agencji prasowych pracujący w Polsce. Jak wiadomo, media są źródłem wielu możliwości dla instytucji kultury, spełniają chociażby funkcję marketingową i popularyzatorską. Bywają jednak również źródłem negacjonizmu czy fałszowania historii poprzez stosowanie hasła „polskie obozy koncentracyjne”. Dobrze zarządzana placówka nie tylko monitoruje sytuację na wielu płaszczyznach świata współczesnego, ale również uczestniczy w dyskursie, nie uchyla się od odpowiedzi i reakcji. Pracownicy PMA-B stworzyli i udostępnili w szesnastu językach aplikację Remember ${ }^{38}$, która wspiera zarówno dziennikarzy, jak i innych zainteresowanych zagadnieniami związanymi z Zagładą, aby nie popełniali powyżej wymienionych, jak i innych błędów. Projekt powstał we współpracy Muzeum i FCB Warsaw oraz przy wsparciu banku PKO BP, Mint Media i Macoscope.

Definicja sformułowana przez Barbarę Czarniawską-Joerges mówi, że organizacje są sieciami zbiorowych działań podejmowanych jako próba kształtowania świata i ludzi. Podążająca tym śladem Katarzyna Barańska podsumowuje, że „zarządzanie to tworzenie więzi”39. Państwowe Muzeum Auschwitz-Birkenau wypracowało z biegiem lat stabilną więź ze światem

37 Przygotowanie do wizyty w Muzeum i Miejscu Pamięci Auschwitz-Birkenau. Pakiet europejski. Wskazówki dla nauczycieli i edukatorów, red. A. Białecka, K. Oleksy, F. Regard, P. Trojański, Oświęcim 2013.

38 correctmistakes.auschwitz.org [dostęp: 11.02.17].

39 K. Barańska, op. cit., s. 168. 
mediów, dowodząc jednocześnie, że miejsce pamięci nie jest przestrzenią martwą, zastygłą w czasie, ale żywą historią, do której wciąż się powraca, historią mającą wpływ na kształtowanie współczesności. Do użytku dziennikarzy z całego świata została oddana strona prasa.auschwitz.org, gdzie poza informacjami związanymi z KL Auschwitz-Birkenau znajdują się wiadomości o aktualnych wydarzeniach czy zasady fotografowania i filmowania w miejscu pamięci. W 2016 roku na terenie Muzeum i Miejsca Pamięci Auschwitz-Birkenau pracowało sto pięćdziesiąt ekip filmowych z całego świata, realizujących m.in. produkcje dokumentalne ${ }^{40}$.

$\mathrm{Na}$ temat strategii zarządzania powstało już wiele publikacji, teorii i badań, jednak skorzystanie $\mathrm{z}$ nich nie jest warunkiem wystarczającym sprawnego kierowania i długofalowego planowania w tak wielowymiarowym miejscu, jakim jest PMB-A. Dyrektor Cywiński podkreśla, że nie można „przyzwyczaić się” do zarządzania miejscami pamięci, nawet jeśli podjęte obowiązki wykonuje się już od wielu lat z równie intensywnym zaangażowaniem:

Auschwitz przerasta. W każdym sensie. Młody człowiek pragnie dorosnąć do tego, co powinien robić, co go czeka, do wyzwań swojego życia. Do Auschwitz nie można dorosnąć. Dojrzeć. [...] Każdy manager ogarnia swym rozeznaniem przestrzeń swojego zarządzania. Mierzy narzędzia na zadanie i wybiera stosowną taktykę. Auschwitz nie da się ogarnąć. Trudno jest zarządzać czymś, czego nigdy się nie ogarnie ${ }^{41}$.

\section{Bibliografia}

Katarzyna Barańska, Muzeum w sieci znaczeń. Zarządzanie z perspektywy nauk humanistycznych, Wydawnictwo Attyka, Kraków 2013.

Piotr M.A. Cywiński, Epitafium... i inne spisane niepokoje, Państwowe Muzeum Auschwitz-Birkenau, Oświęcim 2012.

Dorota Folga-Januszewska, Muzea $w$ Polsce 1989-2008. Stan, zachodzace zmiany i kierunki rozwoju muzeów w Europie oraz rekomendacje dla muzeów w Polsce, MKiDN, Warszawa 2008.

40 Sprawozdanie Państwowego Muzeum Auschwitz-Birkenau w Oświęcimiu za rok 2014, s. 44.

${ }^{41}$ P.M.A. Cywiński, Epitafium..., op. cit., s. 41. 
Alicja Kędziora, Miejsca pamięci w zarządzaniu pamięcią o artyście, „Zarządzanie w Kulturze" 2012, nr 13, z. 2.

Marek Krajewski, Instytucje kultury a uczestnicy kultury. Nowe relacje. Przykład: $M S^{2} w$ Lodzi, [w:] Strategie dla kultury. Kultura dla rozwoju. Zarzadzanie strategiczne instytucja kultury, red. M. Śliwa, Małopolski Instytut Kultury, Kraków 2001.

Nowoczesne zarządzanie muzeum. Współpraca polsko-holenderska w ramach projektu MATRA 1999-2007, red. J. Czaj, B. Ziemnicka-Darnowska, P. Pawlina, Krajowy Ośrodek Badań i Dokumentacji Zabytków, Warszawa 2007.

Edith Penrose, The Theory of the Growth of the Firm, Oxford University Press, Oxford 1959;

Paweł Sawicki, Ponad 2 miliony odwiedzających Miejsce Pamięci Auschwitz-Birkenau w 2016 r., „Oś - Oświęcim - Ludzie - Historia - Kultura” 2017, nr 105.

Ryszard Stocki, Dialog strategiczny w instytucji kultury. Przykład: Wawel i przewodnicy, [w:] Strategie dla kultury. Kultura dla rozwoju. Zarzadzanie strategiczne instytucją kultury, red. M. Śliwa, Małopolski Instytut Kultury, Kraków 2001. Andrzej Szpociński, Miejsca pamięci (lieux de mémoire), „Teksty Drugie” 2008, nr 4. Martyna Śliwa, Zarządzanie strategiczne organizacja, [w:] Strategie dla kultury. Kultura dla rozwoju. Zarzadzanie strategiczne instytucja kultury, red. M. Śliwa, Małopolski Instytut Kultury, Kraków 2001.

\section{Źródła online}

http://auschwitz.org/muzeum/aktualnosci/milion-odwiedzajacych-miejsce-pamieci-w-2015-r-,1741.html.

http://auschwitz.org/muzeum/aktualnosci/nowy-system-rezerwacji-online-w-muzeum-auschwitz,1673.html.

http://auschwitz.org/muzeum/aktualnosci/seminaria-dla-dyrektorow-oraz-wychowawcow-w-zakladach-karnych-i-aresztach-slaska-i-malopolski,1658. html. http://www.fundacja.auschwitz.org/index.php/darczyncy/panstwa. http://www.fundacja.auschwitz.org/index.php/aktualnosci/61-posiedzenie-komitetu-miedzynarodowego-fundacji-auschwitz-birkenau.

www.fundacja.auschwitz.org/index.php/aktualnosci/32-globalny-plan-konserwacji -rozpoczety. 


\section{Strategic Management of the Martyrdom Museum and the Site of Memory - on the Example of the Auschwitz-Birkenau State Museum}

Auschwitz-Birkenau State Museum, located on the territory of the former Nazi's concentration camp, is an example of what a French historian, Pierre Nora, called 'a site of memory' (lieu de mémoire) - a place which serves to commemorate and symbolize the biggest genocide and the tragedy of the twentieth century, that is the Holocaust. Hence, the management of the institution like this has to include both market-based as well as ethical factors. Moreover, since the Museum uses many elements of the original concentration camp's infrastructure, the question arises whether it should aim to preserve the authenticity of this place, or rather follow the main trends in the museology (digitalization, wide multimedia environment etc.). The authoress analyzes the management strategy of the Museum by taking into account the statistical data, its educational offer, as well as the currently realized projects and programs.

Keywords: Auschwitz-Birkenau State Museum, the site of memory, martyrdom museum, cultural management 